\title{
Modulation Found in Translation of Poco Lo Coco Movie
}

\author{
Widya Ningrum ${ }^{1}$, Diana Chitra Hasan ${ }^{2}$, Al Azwad Fauzan ${ }^{3}$ \\ Student in English Department, Bung Hatta University, Jl. Bagindo Aziz Chan, By Pass, Aie Pacah, Koto Tangah, Padang, 25586, Indonesia \\ E-mail: widyaningrum359@gmail.com
}

Lecturer in English Department, Bung Hatta University, Jl. Bagindo Aziz Chan, By Pass, Aie Pacah, Koto Tangah, Padang, 25586, Indonesia E-mail: diana_asril@yahoo.com

Lecturer in English Department, Bung Hatta University, Jl. Bagindo Aziz Chan, By Pass, Aie Pacah, Koto Tangah, Padang, 25586, Indonesia E-mail: Alfauzandjaya@gmail.com

\begin{abstract}
The aims of this study are to find the types of modulation strategy in translation Poco Lo Coco movie and describe the accuracy of modulation of English to Indonesian. The research used a descriptive qualitative method. The data of this research are the utterances or sentences in movie subtitle both English and Indonesian with the source of the data of this research is Poco Lo coco movie.The data collected by watching the movie, and categorized the collected data based on types of modulation strategy and asses accuracy of modulation. The writer find out there are three types of modulation found in the Poco Lo Coco movie such as free modulation, addiction or creation, point of view shift. While the translation using modulation procedure could be concluded categorized as accurate, less accurate and inaccurate.Based on the findings, it can be concluded that there are three from eleven types of modulation are found in the movie subtitle:Poco Lo coco
\end{abstract}

Keywords: translation; modulation; asses of accuracy modulation

\section{INTRODUCTION}

Most of people in all country are enjoy the movie. By watching movies, people can get inspirations, ideas, knowledge, earn something new from the movies, and many others things. On the other hand, when people watch movie in foreign languages; usually they obtain problems in understanding foreign language of the movie. Therefore, the translating is important to make the audience easy to understand the context of the movie. Unfortunately, the common problem that have been faced by the translator is only small portion of people in the world can translate English into target language such as Indonesian. Because the basic capacity as translator of English are the knowledge of culture of source language or the character of the movie and the linguistic aspect of target language. Hollywood movie industry has provided a great opportunity for professional cinematography all around the world including Indonesian country. So, that a lot of movies from Hollywood have been translated into Indonesian language. It can be assume that, the role of translator from English into Indonesian have a great important role for audience of English movie.

Translation is the process of transferring the meaning and information from the source language (SL) into the target language (TL). The process of translation is not easy as the people think, the way to translate does not only need a dictionary, but also requires an understanding the meaning of the context and grammatical background of the source language (SL) to target language (TL). As stated by Nugroho (2016) that the world experiences faster communication and accelerated mobility, translation studies takes part as a bridge to avoid a communication gap. That is why the translator is needed to make a good way in translating as the communication in the world. There are a lot of strategy use in translation technique. But, in translating process the writer chooses one of the translation strategies that is modulation strategy. Modulation is using the different phrase in the source language and target language but in result has the same idea. Machali (2000: 67-69) analyzes 
that translation strategy from English into Indonesian, one of the strategy is modulation. Through modulation is to obtain meaning equivalence between the meaning of SL and TL. It makes the audience are easy to understand the content of the text.

Poco Lo Coco is an American 3D computer animated fantasy film produced by Pixar Animation Studios and released by Walt Disney Pictures. Based on an original idea by Lee Unkrich, it is directed by him and co-directed by Adrian Molina. This movie obtain many awards, such as coco was choosen by the National Board of Review as the Best Animated Film of 2017, the film won two Academy Awards for Best Animated Feature and Best Original Song ("Remember Me"), it also won the Best Animated Film at the BAFTA Awards, Golden Globe Awards, Critic's Choice Movie Awards, and Annie Awards. The genre of this movie is Adventure, Animation, and Family.

The main character in this movie is Miguel Rivera, 12 years old boy who is accidentally transported to the land of the dead, where he seeks the help of his deceased musician great-greatgrandfather to return him to his family among the living. He simply loves music; but his family has a mysterious ban on anyone from their clan performing music. The ban dates back for many generations yet Miguel dreams of becoming an accomplished musician just like his idol, Ernesto de la Cruz. Longing to prove his musical talents, Miguel finds himself in the technicolor Land of the Dead. Along his way, he meets the charming trickster Hector, and together, they set out to find the real story behind his family's mysterious ban on music. After he found his great-great grandfather Hector, then Imelda blessed Miguel with no conditions attached so he can return to the Land of the Living, The song sparks her memory of Hector and revitalizes her, and she gives Miguel the tornout piece of the photo from the Ofrenda, which shows Hector's face. Elena reconciles with Miguel, accepting both him and music back into the family.

Based on the explanation above, this research is specified on classify the types of modulation found in the Poco Lo Coco movie from English to Indonesian and determining the accuracy of modulation of English to Indonesian subtitle using modulation technique in Poco Lo Coco movie texts.

The purposes of the research are; To find out the types of modulation found in Poco Lo Coco Movie and find out the accuracy of modulation of English to Indonesian in Poco Lo Coco Movie.

\section{THEORETICAL REVIEW}

The researcher explains the combination of theory and the concept to support and to give more information about this research. Furthermore, the researcher also describes the previous studies about this research as a reference. This research analyzes types of modulation found in Poco Lo Coco's movie and the asses of accuracy modulation by using some theories to analyze the data.

\section{A. Modulation Procedures}

According to Machali (2000: 69) there are two types of modulation :

a) Obligatory Modulation

Obligatory modulation occurs when words, phrases, or other grammatical structures do not have similarity in target language. Obligatory modulation can also happen in word translation of which only some meaning parts of the source language, from specific into general meaning.

Thenclassifies modulation into three types:

1) Addition/creation of linguistic units, modulation is done if a word, phrase or other linguistic units do not have equivalence in TL, so it should be added/created.

For example:

a. English : Unique is the word that best captures Singapore - a dynamic, cosmopolitan city-state where different cultures, ethnic groups and religions blend harmoniously.

b. Indonesia: Unik adalah kata yang tepat untuk mendeskripsikan Singapuranegara berukuran kota kosmopolitan yang dinamis, yang memiliki banyak kebudayaan yang berbeda, kelompokkelompok etnik dan keharmonisan dari beragam agama.

In the data above, there is no equivalence of noun phrase 'city-state' in TL, so it is created a phrase 'negara berukuran kota' (Purnomo, 2015). 
2) Specific-general meaning, modulation is done for a word translation in which only a part of its meaning aspects in SL can be expressed in TL, i.e. from specific meaning to general meaning.

For example:

a. SL: Man is a thinking animal.

\section{TL: (a) Manusia adalah makhluk yang berpikir. \\ (b) Manusia adalah hewan yang berpikir.}

[Hasan, 2008, p. 35]

b. SL: The Indonesian tourist industry is one of the major non-oil and gas income producers for Indonesia. Each year a total of 3 million tourists from over forty countries visit the archipelago.

TL: (a) industry turisme Indonesia merupakan salah satu penghasil pendapatan nonminyak/gas untuk Indonesia. Tiap tahun sebanyak tiga juta turis luar negeri dari lebih 40 negara mengunjungi kepulauan Indonesia.

(b) Industry pariwisata Indonesia merupakan salah satu penghasil pendapatan nonmigas bagi Indonesia. Setiap tahun sebanyak tiga juta wisatawan mancanegara dari lebih 40 negara mengunjungi kepulauan Indonesia.

In the data above, word 'visitor' that lexically means 'pengunjung' in TL is translated into 'wisatawan' in order to obtain general meaning. Moreover, the word 'wisatawan' is broadly known and accepted as an appropriate term in tourism industry (Purnomo, 2015).

2) Clarified meaning and natural equivalence, modulation is done that aims to clarify and find natural equivalence in TL.

For example:

a. SL: There are also the usual hotels, quaint inns, boarding houses and campsites, not far from the blaze of tulips.

b. TL: Terdapat juga hotel-hotel biasa, penginapan kecil dan pondok wisata serta lapangan perkemahan tidak jauh dari gemerlapnya tulip.

In the data above, noun phrase 'boarding house' that literally means 'rumah indekos' is translated into 'pondok wisata' in order to clarify meaning, more natural in TL and has been broadly used in tourism terminology (Purnomo, 2015).

b) Free Modulation

Free modulation is translation procedure employed for non-linguistic purposes, such as to clarify meaning, to create a connection in TL, to find equivalence that seems natural in TL. In translation world, it is called explicatory, making the meaning clearer.

For example :

a) SL : Environtment degradation.

TL : Penurunan mutu lingkungan.

[Hasan, 2008, p. 35]

State implicitly from the receptor's language into the source's language. The translator addition a implicit meaning express with the word 'mutu' to make the data transferred to the audiences.

[Hasan, 2008, p. 35]

b)SL : We all suffer from the consequences of environtmental degradation.

TL : Kita semua menderita karena adanya penurunan mutu lingkungan (Machali, 2000).

c) SL : Conflicts are bound to occur.

TL : Konflik militer tak urung terjadi juga.

Positive statement in the source's language changes into double negative statement in the receptor's language (Machali, 2000).

\section{B. Criteria to Asses Accuracy of Modulation}

In this research, the researcher applied criteria to a assess accuracy of using modulation which can described into the following diagram. Purnomo states there are three types of asses accuracy of modulation.

TABLE 1.

ASSES ACCURACY OF MODULATION 


\begin{tabular}{|c|c|c|}
\hline $\begin{array}{l}\text { Modulation } \\
\text { Strategy }\end{array}$ & Category & Criteria \\
\hline \multirow{3}{*}{ Modulation } & $\begin{array}{l}\text { Accurate } \\
\text { modulation }\end{array}$ & $\begin{array}{l}\text { (1) Use of } \\
\text { words or } \\
\text { expressions in } \\
\text { TL that have } \\
\text { equivalent } \\
\text { meaning with } \\
\text { SLand } \\
\text { (2)equivalence } \\
\text { seems natural } \\
\text { and commonly } \\
\text { used by TL } \\
\text { speakers. }\end{array}$ \\
\hline & $\begin{array}{l}\text { Less accurate } \\
\text { modulation }\end{array}$ & $\begin{array}{l}\text { (1) Use of } \\
\text { words or } \\
\text { expressions in } \\
\text { TL that do not } \\
\text { have } \\
\text { equivalent } \\
\text { meaning with } \\
\text { SL, but the } \\
\text { message has } \\
\text { been } \\
\text { transferred } \\
\text { and (2) } \\
\text { equivalence } \\
\text { seems less } \\
\text { natural and } \\
\text { less commonly } \\
\text { used by TL } \\
\text { speakers. }\end{array}$ \\
\hline & $\begin{array}{l}\text { Inaccurate } \\
\text { modulation }\end{array}$ & $\begin{array}{l}\text { (1) Use the } \\
\text { words or } \\
\text { expressions in } \\
\text { TL that do not } \\
\text { have } \\
\text { equivalent } \\
\text { meaning with } \\
\text { SL and the } \\
\text { message has } \\
\text { not been } \\
\text { transferred } \\
\text { and (2) } \\
\text { equivalence } \\
\text { seems unnatural and } \\
\text { uncommonly } \\
\text { used by TL } \\
\text { speakers }\end{array}$ \\
\hline
\end{tabular}

\section{Accuracy of Modulation}

In this research, the writer found example of accuracy of modulation in three types. Purnomo states in his journal Transportation and modulation to translate tourism texts from English into Indonesian. There are accurate modulation, less accurate and inaccurate modulation.

Accurate modulation is use of words or expressions in TL that have equivalent meaning with SL and equivalence seems natural and commonly used by TL speakers.

SL : After many bankruptcies, the crisis was ended by government regulation of the tulip trade.

TL : Setelah beberapa kali kebangkrutan, krisis tersebut diakhiri oleh peraturan pemerintah mengenai perdagangan tulip.

In the data above, translation of plural marker "many" does not use "banyak" that has wide meaning, but uses "beberapa kali" that has narrower meaning and acceptable in TL as modulation strategy. This modulation is accurate because it relates to trading efforts in which the risk is profit and loss, even bankrupt. The word "banyak" is more appropriate if it collocates with word "keuntungan" and "kerugian" becomes "banyak keuntungan" dan "banyak kerugian". Related to "kebangkrutan", collocation "banyak kebangkrutan" is uncommon in Indonesia speakers. The common collocation is "beberapa kali kebangkrutan". So, it can be concluded that in meaning aspect, the linguistic unit-translation has used words or expressions which have equivalent meaning with SL and the equivalence is natural and commonly used by TL speakers (Purnomo, 2015).

Less accurate modulation is use of words or expressions in TL that do not have equivalent meaning with SL, but the message has been transferred and equivalence seems less natural and less commonly used by TL speakers.

SL : Touring through such tulips has become a rite of spring in Holland, although you can drive through most of the country and see no more tulips than at home.

TL : Menikmati kumpulan bunga tulip telah menjadi semacam upacara Musim Semi di Negeri Belanda walau Anda dapat berkendaraan ke sebagian besar negeri tetapi tidak akan melihat tidak lebih banayak tulip daripada di rumah.

In the data above, to translate word "Touring" into "Berwisata menikmati" is more accurate than into "Menikmati" and word "drive" into "mengunjungi" is more accurate than into "berkendaraan". To naturalize translation, it is 
more accurate to change phrase "tetapi tidak akan melihat tidak lebih banyak tulip dari pada" into "dan tidak dapat melihat lebih banyak tulip sebagaimana di negeri Anda sendiri". It can be concluded that the data above translation does not use words or expressions that have equivalent meaning with SL but the message has been transferred and the meaning is less natural and less common in TL (Purnomo, 2015).

To translate the above sentence with accurate modulation, the researcher make improvement alternative as follows.

\section{Alt: Berwisata menikamati kumpulan bunga tulip telah menjadi semacam upacara Musim Semi di Negeri Belanda. Walaupun Anda dapat mengunjungi ke banyak negara tetapi Anda tidak akan melihat lebih banyak tulip sebagaimana yang ada di Negara Anda sendiri. (Purnomo, 2015).}

Inaccurate modulation is Use the words or expressions in TL that do not have equivalent meaning with SL and the message has not been transferred and equivalence seems unnatural and uncommonly used by TL speakers.

SL : It's a good idea to have your travel agent make reservations a year in advance.

\section{TL : Ada baiknya Anda mengatur perjalanan Anda setahun di muka.}

In this data above, if meaning of the above sentence translation is analyzed, there is an inaccurate meaning shift (modulation). Clause "to have your travel agent make reservations" is inaccurately translated into "Anda mengatur perjalanan Anda". The accurate one is "agen perjalanan wisata Anda melakukan pemesanan". In this context, there is a meaning shift in which the subject is "your travel agent", but it changes into "you" (tourist). Besides that the equivalence of "make reservations" that is translated into "mengatur perjalanan" is not equivalent. The accurate equivalence is "melakukan pemesanan". Moreover, the translation is unnatural and uncommonly for TL speakers. It can be concluded that there is no equivalent meaning between the SL and the TL. In other words, it can be stated that the above sentence translation does not use words or expressions that have equivalent meaning and the message is not well transferred (Purnomo, 2015).

To translate the above sentence with accurate modulation, the researcher make an improvement alternative as follow.

\section{Alt : Ada baiknya agen perjalanan wisata Anda melakukan pemesanan setahun di muka.}

The above research findings support the findings of Kasghari (2011) who found that translating using equivalence is not necessarily the best strategy, i.e. it does not produce a meaningful rendering of the source term [ST] in Arabic into the target term [TT] in English. To solve it, using noequivalence strategy can also be applied to translate texts from English into Indonesian.

An easy way to comply with the journal paper formatting requirements is to use this document as a template and simply type your text into it (Purnomo, 2015).

\section{RESEARCH METHODOLOGY}

In this research method, the researcher analyzes the modulation techniques in translation based on the data on subtitle text of the movie. According to Berg (2007) in his book Qualitative research methods for the social sciences sixth edition claimed that qualitative research interprets to the meanings, concepts, definitions, characteristics, metaphors, symbols and description things. Therefore, qualitative method is a process of understanding, events and relationships in social and cultural context. The researcher examines about the source of data, technique of collecting data and technique of representing the data. Source of the data were taken from the Subtitle Text of Coco movie. The Indonesian subtitle translated by Deni Auror@.According to Arikunto (2006) technique of documenting is searching data about things by using documents such as notes, transcripts, books, newspaper, magazine, and journal. The researcher choose documentation as technique of collecting data. The researcher has some ways to collect the data. Firstly, watched the movie many times. Secondly, downloading the script and the subtitle of the movie. Thirdly, read the script and observe the types of modulation and also the assess accuracy of modulation found in the movie. Then, the 
researcher classifies the data that contain of types of modulation and the assess accuracy of modulation. Finally, the data can be present and explain to the audiences in this research. After the data were collected, the researcher continued to analyze the data. It will be conducted based on the research question and the findings that the researcher will use to analyze. This step will identified by method of the research with approach, after each of data had classified.

According to Surdayanto (1993:145) there are two methods as technically used, formal and informal methods. In term of informal method is the result of analysis will be presented and explained by using ordinary words. Meanwhile, the formal method is the analysis done by doing sign, symbols, tables. The researcher explains the data in conversation found in the subtitle of the movie. Then, the researcher explains in the descriptive paragraph about types of modulation found and the asses accuracy of modulation found in the movie.

\section{FINDING AND DISCUSSION}

\section{A. FINDING}

The researcher would like to find out and analyze the types of translation found in the Coco's movie and the assess accuracy of modulation. There are three types of modulation strategy found in the Coco's movie; free modulation, addition or creation, point of view shift and there are three types of accuracy in translation such as accurate modulation, less accurate modulation, and inaccurate modulation.

The researcher found there are three types of modulation procedures in the Poco Lo Coco Movie the data are: five free modulation, five point of view and five addition.

\section{Example (1) Free Modulation}

SL: Or a sausage someone dropped in a barbershop.

\section{TL: Atau sosis, seseorang telah menjatuhkannya.}

The translator do not translating the location of the text 'barbershop' and decide to cut the meaning without additional information of place. But, the translator do not put the 'barbershop' in the translation text because the movie already show about the condition of the dog such as dirty, pale skin and imagine if that dog perhaps like a 'sausage someone dropped in a barbershop'and it is the shortcut to make the audiences understand what the translator mean about the movie. So, the translator unnecessary put the location on the subtitle text of the movie. So, it can be concluded that in meaning aspect, the linguistics unit translation of the data above is accurate. It can be stated that the above sentence translation has used words or expressions which have equivalent meaning with SL and the equivalence is natural and commonly used by TL speakers or the data include on Accurate Modulation.

Example (2) Point of view

\section{SL : It's no future for my son.}

\section{TL : Ini bukan masa depan untuk anakku.}

The translator using point of view shift in translated the text. The translated of 'It's no future for my son' into 'Ini bukan masa depan untuk anakku' in TL. The word 'ini bukan' its make the sentence have point of view shift, it can assume that the translator saw the future of her son it's not music based on the context. But, the future for the her son is to be a shoemakes as her family tradition. In other side, the translator also can assume that the son exactly did not have future in his life if he choose music based on the contextof the textand the translate in TL 'ini bukan'also can assume as a two option that the son can choose. It can conclude, the son have his future if he is do not choose music as his dream. In addition, the accuracy of the text include on Less Accurate Modulation. The reason is the audiences hard to understand the text because the translator do not use the natural language and do not make it clear in meaning. It can be concluded that the translation above does not use words or expressions that have equivalent meaning with SL but the message has been transferred and the meaning is less natural and less common in TL.

Example (3) addition

$$
\begin{aligned}
& \text { SL : Whoa, shoot. } \\
& \text { TL : Whoa, kena kau. }
\end{aligned}
$$

The meaning of shoot in SL translating into Indonesian becomes 'tembak, menembak'. In the context of the text the translator translating 'shoot' 
into 'kena kau'. In the movie, Hector imitate Frida Kahlo his ex wife and wish he can pass the photo scanner but, there is nobody put up his photo on ofrenda and the officer say the word 'kena kau' because he often doing the trick to zip over to accros the bridge. Then, Hector under a rest because of his act. So, the translator choose 'kena kau' to make the meaning more emphasis to the context of text. In accuracy of modulation the data include in Less Accurate modulation. The reason is the audiences hard to understand the text because the translator do not use the natural language and do not make it clear in meaning. It can be concluded that the translation above does not use words or expressions that have equivalent meaning with SL but the message has been transferred and the meaning is less natural and less common in TL.

\section{B. DISCUSSIONS}

The researcher found there are three types of modulation procedures in the Poco Lo Coco movie and analyze each of procedures found with accuracy of modulation. The purpose is to make the researcher easy to consider the accurate, less accurate, and inaccurate. As the result, the researcher compare between two translation from two different translator. So, the researcher could see and compare which one enough or better in translation side. In other side, the translation has a big impact to the movie world or not.

\section{CONCLUSIONS}

After studying about types of modulation strategy in translation procedure and assess accuracy of modulation, the researcher states the conclusion as follow: To translate the language from SL to TL need a base knowledge as translator. The translator need to well-known about the differences between the meaning of word. What the prefer word will use to translate the text and vice versa. In translating English into Indonesian, it needs translation equivalent between source language (SL) and target language (TL), to fulfil this need applying translation theory. The modulation strategy is one of the translation procedures in linguistic units. In the research the researcher focus on one of the translation theory is modulation strategy. The researcher wants to see the types in modulation strategy found in the Poco Lo Coco's movie.
Based on data the researcher found there are three types modulation strategy such as addiction/creation, free modulation and point of view shift. Beside of that, the researcher also analyze about assess accuracy of modulation and found there are accurate modulation, less accurate modulation and inaccurate modulation in the text. The researcher decide to choose the modulation strategy to analyze the data is to make the audiences can obtain the equivalent information from SL and TL have the same meaning of translation.

\section{REFERENCES}

[1] Berg, B. (2007). Qualitative Research Methods for the Social Sciences (6TH ed.). San Francisco: Pearson

[2] Catford, J. C. 1965. A linguistic Theory of Translation. London: Oxford university Press.

[3] Hasan, Diana Chitra. 2008. Penerjemahan Metafora Bahasa Inggris ke Bahasa Indonesia. Padang : Bung Hatta University Press.

[4] Kashgari, Amira D. (2011). The Paradox of Translating the Unstranslatable: Equivalence vs. Non-Equivalence in Translating from Arabic into English. Journal of King Saud University-Language and Translation, 23: 47-57.

[5] Larson, L. Midred. 1988. Meaning Based Translation, A Guide to Cross Language Equivalence. University Press of the America, Inc: USA.

[6] Machali, Rochayah (2000). Pedoman Bagi Penerjemah. Jakarta: PT Grasindo

[7] Molina, L., \& Hurtado Albir, A. (2002). Translation techniques revisited: a dynamicand functionalist approach. Meta XLVII, 4, 498512. $\quad$ Retrieved from https://ddd.uab.cat/pub/artpub/2002/137439/meta_a2002v47n4p498. pdf

[8] Newmark, P. (1998). A Text Book of Translation. New Jersey Prentice Hall.

[9] Nida, a. Eugene and Taber, R Charles. 1969. The Theory and Practice of Translation. Hall International (UK) Ltd.

[10] Nugroho, Raden Arief, et al. (2016). Translation Microstrategies Used by Visually impaired Translator in International Journal of English Linguistics. Vol. 6. No. 5. P .103. DOI : http //doi.org/10.5539/ijel.v6n5p103.

[11] Pamungkas, Muhammad Noor. (2017). Meaning Equivalence of Modulation Techniques in Gie's Bahasa Indonesia-English Movie texts.

[12] Purnomo, Budi (2015). Transpositition and Modulation to Translate Tourism Texts from English into Indonesian. Arab World Journal (AWEJ). Vol. 6. No. 3. Pp. 219-229.

[13] Sudaryanto. 1993. Metode dan Aneka Teknik Analisis Bahasa: Pengantar Penelitian Wahana. 